\title{
T-Cell Surface Glycoprotein CD1a
}

National Cancer Institute

\section{Source}

National Cancer Institute. T-Cell Surface Glycoprotein CD1a. NCI Thesaurus. Code C97923.

T-cell surface glycoprotein CD1a (327 aa, $37 \mathrm{kDa}$ ) is encoded by the human CD1A gene.

This protein is involved in the mediation of lipid and glycolipid antigen presentation. 